\title{
Cyclosporine or FK506 Decrease Mature Epidermal Growth Factor Protein Expression and Renal Tubular Regeneration in Rat Kidneys with Ischemia/Reperfusion Injury
}

\author{
Chul Woo Yang Seung Hun Lee Sun Woo Lim Ju Young J ung \\ Wan Young Kim Hyung Wook Kim Bum Soon Choi Can Li J ung Ho Cha \\ Yong Soo Kim J in Kim Byung Kee Bang
}

Departments of Internal Medicine and Anatomy, College of Medicine, The Catholic University of Korea,

Seoul, Korea

\section{Key Words}

Cyclosporine - FK506 - Epidermal growth factor . Ischemia-reperfusion injury

\begin{abstract}
Background: Epidermal growth factor (EGF) plays an important role in tubular regeneration in kidneys with ischemia/reperfusion (I/R) injury. This study was undertaken to evaluate the influence of cyclosporine $A$ (CsA) or FK506 on mature EGF expression and tubular regeneration in rat kidneys with I/R injury. Methods: Two separate studies were performed. First, the expression of EGF and tubular regeneration was observed in rat kidneys with I/R injury on days $1,2,3,5$, and 7 . Second, the dose-dependent response of EGF expression and tubular regeneration to CsA (5, 10, and $20 \mathrm{mg} / \mathrm{kg})$ or FK506 (0.25, 0.5, and $1.0 \mathrm{mg} / \mathrm{kg}$ ) was observed in rat kidneys with I/R injury. I/R injury was induced by clamping both renal arteries for 45 min, and CsA or FK506 was injected just after release of vascular clamps. Rats were sacrificed on day 1 for evaluation of EGF expression, and on day 2 for evaluation of BudU-positive cells. Renal function, tubular injury score, EGF expression assessed by immunoblotting, lev-
\end{abstract}

els of CSA and FK506 in whole blood, and immunostaining for BrdU was studied. Results: EGF expression was maximal on day 1 (cortex, 29-fold; medulla, 31-fold compared with sham-operated controls), and renal tubular regeneration measured with the number of BrdU-positive cells was maximal on days 2 and 3 in kidney with I/R injury, and thereafter the level of EGF and the number of BrdU-positive cells decreased progressively. CsA or FK506 treatment to ischemic rat kidneys reduced the expression of EGF and the number of BrdU-positive cells in a dose-dependent manner. Conclusions: CsA or FK506 treatment delays recovery from acute tubular necrosis, and this may be associated with decreased EGF expression by CSA or FK506.

Copyright $\odot 2002$ S. Karger AG, Basel

\section{Introduction}

Ischemia/reperfusion (I/R) injury is unavoidable in renal transplantation, occurring during organ retrieval and storage. It has been demonstrated in experimental models that the initial insult may increase the immunogenicity of the organ by upregulating MHC class II antigens,

\begin{tabular}{ll}
\hline KARGER & ( 2002 S. Karger AG, Basel \\
0028-2766/02/0924-0914\$18.50/0 \\
$\begin{array}{l}\text { Fax +41613061234 } \\
\text { E-Mail karger@karger.ch } \\
\text { ww.karger.com }\end{array}$ & $\begin{array}{l}\text { Accessible online at: } \\
\text { www.karger.com/journals/nef }\end{array}$
\end{tabular}

Prof. Jin Kim
Department of Anatomy, The Catholic University of Korea
505 Banpo-Dong
Seocho-Ku, Seoul 137-040 (Korea)
Tel. +82 2590 1153, Fax +82 2536 3110, E-Mail jinkim@catholic.ac.kr 
and this is closely associated with increased acute rejection episode. In addition, I/R injury in the early transplant period has been associated with late allograft failure [1-5].

The kidney has a remarkable capacity for restoring its structure and function after acute ischemic renal failure [6-8]. Experimental data suggest that the recovery of renal function after ischemic injury is due to a replicative repair process involving renal tubule cells, and predominantly depends on the release of paracrine or autocrine growth factors $[9,10]$. Of these, epidermal growth factor (EGF) is a 53 amino acid $(6.2 \mathrm{kD})$ polypeptide that stimulates the proliferation and differentiation of epithelial cells and is mitogenic for various other cell types in culture $[11,12]$. Furthermore, EGF is thought to be important in the maintenance of renal tubule integrity and in the tubular regenerative response to injury $[13,14]$. Animal studies have shown that EGF accelerates renal tubular regeneration in rat models of acute renal failure [15], whereas treatment with anti-EGF antibody inhibits tubular cell proliferation during compensatory renal growth [16].

The nephrotoxic effects of CsA and FK506 are potentiated by ischemic injury, an important problem in the early posttransplant period [17]. Concomitant treatment with cyclosporine (CsA) of a graft with $\mathrm{I} / \mathrm{R}$ injury delays the recovery of graft function [18] in renal transplantation. This finding suggests that CsA may inhibit renal tubular regeneration in kidneys with $I / R$ injury, but influence of CsA on intrarenal growth factor is not fully understood. On the basis of the findings described above, we proposed the hypothesis that CsA or FK506 may delay renal tubular regeneration by decreasing EGF protein in rat kidneys with $\mathrm{I} / \mathrm{R}$ injury. To test this hypothesis, EGF expression and renal tubular regeneration was evaluated in CsA or FK506-treated ischemic rat kidney. The results of our study demonstrate an association of CsA- or FK506-induced nephrotoxicity and intrarenal EGF expression in rat kidneys with $\mathrm{I} / \mathrm{R}$ injury.

\section{Materials and Methods}

\section{Animals and Drugs}

Adult male Sprague-Dawley rats, weighing approximately 250$300 \mathrm{~g}$, were housed in individual cages in a temperature- and lightcontrolled environment under a 12-hour light, 12-hour dark cycle, and food and water were available ad libitum. CsA provided by Norvatis Co. (East Hanover, N.J., USA) was diluted in olive oil to a final concentration of $20 \mathrm{mg} / \mathrm{ml}$. FK506 provided by Fujisawa pharmaceutical Ltd. (Osaka, Japan) was diluted in saline and injected subcutaneously.

EGF Expression in CsA- or FK506-Treated

Ischemic Rat Kidneys

\section{Experimental Group}

The experimental protocol was approved by the animal ethics review committees of our institutions. Two separate protocols were used. Expression of EGF and renal tubular cell regeneration in ischemic rat kidneys were evaluated in protocol 1, and influence of CsA or FK506 on EGF expression and renal tubular regeneration in ischemic rat kidneys was studied in protocol 2.

Protocol 1. Expression of EGF and renal tubular cell regeneration in rat kidneys with $I / R$ injury were studied. $I / R$ injury was induced by clamping both renal arteries for $45 \mathrm{~min}$, and animals were sacrificed $1,2,3,5$ and 7 days after I/R injury. For evaluation of renal tubular cell regeneration, $5 \mathrm{ml} / \mathrm{kg}$ of BrdU (Roche Molecular Biochemicals, Mannheim, Germany) was injected intraperitoneally (18, 10 and $2 \mathrm{~h}$ before sacrifice) and animals sacrificed 1, 2, 3, 5 and 7 days after I/R injury. Six animals were included at each time.

Protocol 2. To define the dose-response, CsA $(5,10,20 \mathrm{mg} / \mathrm{kg})$ or FK506 $(0.25,0.5$, and $1.0 \mathrm{mg} / \mathrm{kg})$ were administered subcutaneously to the rats just after ischemic injury. The rats were sacrificed $24 \mathrm{~h}$ later for evaluation of EGF expression, and $48 \mathrm{~h}$ later for evaluation of BrdU-positive cells. BrdU (Roche Molecular Biochemicals, Mannheim, Germany) was injected as described above. Six animals were included at each time and dose.

The rats were anesthetized with intraperitoneal ketamine, and the abdomen was opened through a midline incision. The aorta was cannulated regrogradely below the renal arteries with an 18-gauge needle. Opened by a small incision for outflow, the kidneys were perfused with PBS. The left kidney was removed and processed for light microscopy. After removing the right kidney, the cortex was dissected from the medulla. After the experiment, the animals were euthanized by deep anesthesia with ketamine followed by exsanguinations.

\section{Functional Studies}

Assessment of acute renal failure was determined by measuring the concentration of blood urea nitrogen and creatinine in serum. Blood urea nitrogen and serum creatinine was measured by a Cobas autoanalyzer (Roche Diagnostics, Div. Hoffman-La Roche Inc., Nutely, N.J., USA). Whole blood CsA levels were measured by a monoclonal radioimmunoassay (Incstar Co., Stillwater, Minn., USA), and whole blood FK506 blood levels were measured by enzyme immunoassay (Abbott Laboratories, Ill., USA)

\section{Histology}

Renal tissues were embedded in wax. Four-micrometer sections were stained with periodic acid-Schiff (PAS) reagents. Tubular injury was scored semiquantitatively using a scoring system ranging from 0 to 4 by a blinded observer who examined at least 40 fields $(\times 200$ magnification). Tubular injury was defined as a tubular dilatation, sloughing of tubular epithelial cells, or naked tubular basement membrane. Only tubules in the outer stripe of the outer medulla (most sensitive zone for ischemic injury) were included in the following scoring system: $0=$ no tubular injury; $1=<1-20 \%$ of tubules injured; $2=21-50 \% ; 3=>51-75 \% ; 4=76-100 \%$.

\section{Renal Tubular Cell Regeneration Using Immunohistochemistry} of BrdU

DNA synthesis in proliferating cells was revealed by the immunolabeling of BrdU incorporated into DNA, as detailed by others [20]. Tissue sections were exposed to a mouse anti-BrdU monoclonal antibody. The presence of immunocomplexes was visualized by combin- 
Fig. 1. Immunoblot of EGF in rat kidney after sham operation or I/R injury. Representative immunoblot for EGF and relative optical densities in the cortex (a) and medulla (b). Note the significant increase in EGF expression on day 1 after ischemia/reperfusion injury. Optical densities represent the mean \pm SEM from six animals. $* p<0.05$ vs. sham-operated rat kidney. a
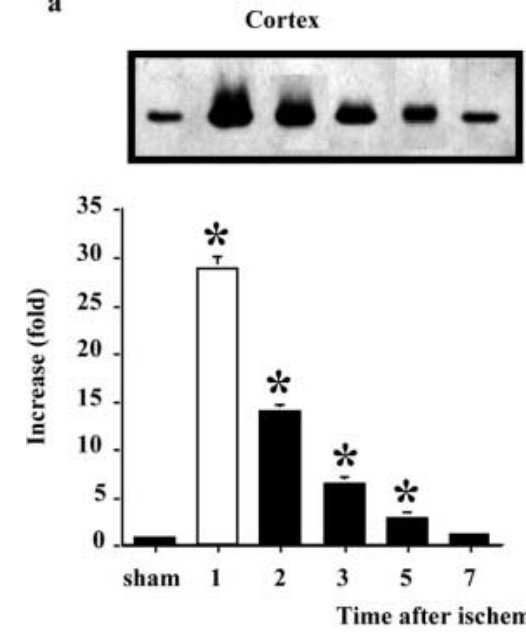

b
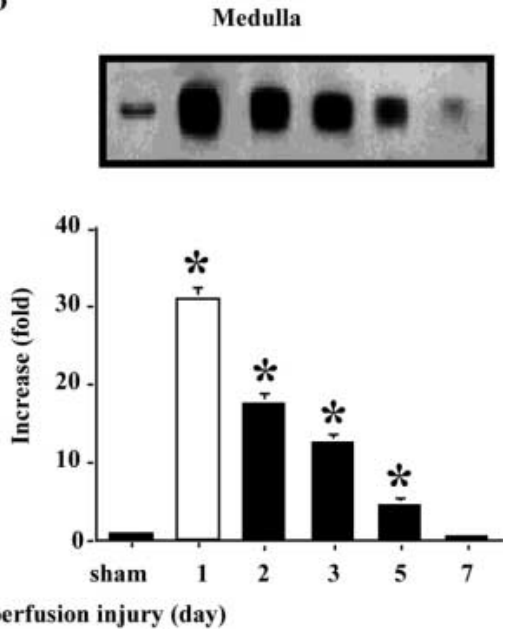

ing two methods, namely the avidin-biotin complex and peroxidase antiperoxidase complex (PAP) procedures. Bound peroxidase activity was detected by incubating tissue sections in the presence of $\mathrm{H}_{2} \mathrm{O}_{2}$ and 3-3'-diaminobenzidine. The procedure was completed by counterstaining with periodic acid-Schiff, hemalum, and Luxol fast blue to allow the identification of histological structures. BrdU-containing nuclei stained brownish and could be easily distinguished from the background. The number of BrdU-positive cells was averaged at 10 fields under the $\times 400$ magnification.

\section{Immunoblotting for EGF}

Kidneys were homogenized in RIPA $(10 \mathrm{mmol} / \mathrm{l}$ Tris $\mathrm{Cl}[\mathrm{pH} 7.6]$ $150 \mathrm{mmol} / \mathrm{L} \mathrm{NaCl}, 1 \%$ [wt/vol] sodium deoxycholate, $1 \%$ [vol/vol] Triton X-100, 0.1\% [wt/vol] SDS, $1 \%$ [vol/vol] aprotinin, $2 \mathrm{mmol} / 1$ $\mathrm{Na}_{3} \mathrm{VO}_{4}$, and freshly added leupeptin $[1 \mu \mathrm{g} / \mathrm{ml}]$, pepstatin $[1 \mu \mathrm{g} / \mathrm{ml}]$, and $1 \mathrm{mmol} / \mathrm{l}$ phenylmethylsulfonylfluoride [PMSF]). Homogenates were centrifuged at $16,000 \mathrm{~g}$ for $15 \mathrm{~min}$ at $4^{\circ} \mathrm{C}$, and protein concentrations were determined using a protein microassay of Bradford method (Bio-rad, Hercules, Calif., USA). Homogenates were heated at $94^{\circ} \mathrm{C}$ for $5 \mathrm{~min}$. Proteins were separated by SDS-PAGE in $15 \%$ polyacrylamide gels and were electroblotted onto Bio-Blot nitrocellulose (Costar, Cambridge, Mass., USA). Nonspecific binding was blocked by incubating the blots for $1 \mathrm{~h}$ in $5 \%$ (wt/vol) nonfat milk. EGF was detected by incubating for $1 \mathrm{~h}$ with a polyclonal anti-EGF antibody (Santa Cruz Biotechnology, Inc., Santa Cruz, Calif., USA) diluted 1:1,000. Primary antibody incubation was followed by six washes of Tris-buffered saline (TBS-T) with $0.005 \%$ tween 20 (TBS$\mathrm{T}$ ). The blot was then incubated with secondary antibody (goat antirabbit IgG-horseradish peroxidase (HRP) conjugate at 1:10,000; (Biorad, Hercules, Calif., USA) for $30 \mathrm{~min}$. Antibody-reactive protein was detected using enhanced chemiluminescence (Amersham Life Science, UK). Densitometric analysis was performed using Gelexpert software (Nucleotech Corp., San Carlos, Calif., USA). Optical densities (mean \pm SEM) were obtained after three determinations for each band in three different gels. EGF expression was described throughout as the proportional (-fold) increase or decrease relative to the levels observed in the sham-operated rat kidney.

\section{Statistical Analysis}

Data recorded are mean \pm SEM, and multiple comparisons among groups were performed by one-way ANOVA with the post hoc Bonferroni test (SPSS 9.0 Microsoft). Pooled sample of all shamoperated animals was used as control since the sham-operated rats showed no significant variations at anytime. The level assumed for statistical significance was $\mathrm{p}<0.05$.

\section{Results}

\section{Expression of EGF and Tubular Regeneration in Rat} Kidney with $I / R$ Injury

Immunoblotting to detect the EGF protein produced a single band of $6.3 \mathrm{kD}$ (fig. 1). The expression pattern of EGF protein was similar in the cortex and medulla. A striking increase was observed in rats with $\mathrm{I} / \mathrm{R}$ injury on day 1 compared with the sham-operated controls (cortex, 29-fold; medulla, 31-fold), and thereafter the level of EGF decreased progressively: day 2 (cortex, 14-fold; medulla, 18-fold), day 3 (cortex, 6.5-fold; medulla, 13-fold), day 5 (cortex, 3-fold; medulla, 5-fold), and day 7 (cortex, 1.5fold; medulla, 1.1-fold).

Figure 2 describes the renal tubular regeneration detected by BrdU-positive cells in sham-operated and ischemic rat kidneys. BrdU-positive cells were rare in the sham-operated rat kidneys $(1 \pm 1$ per field). In the kidneys with $\mathrm{I} / \mathrm{R}$ injury, the number of BrdU-positive cells 


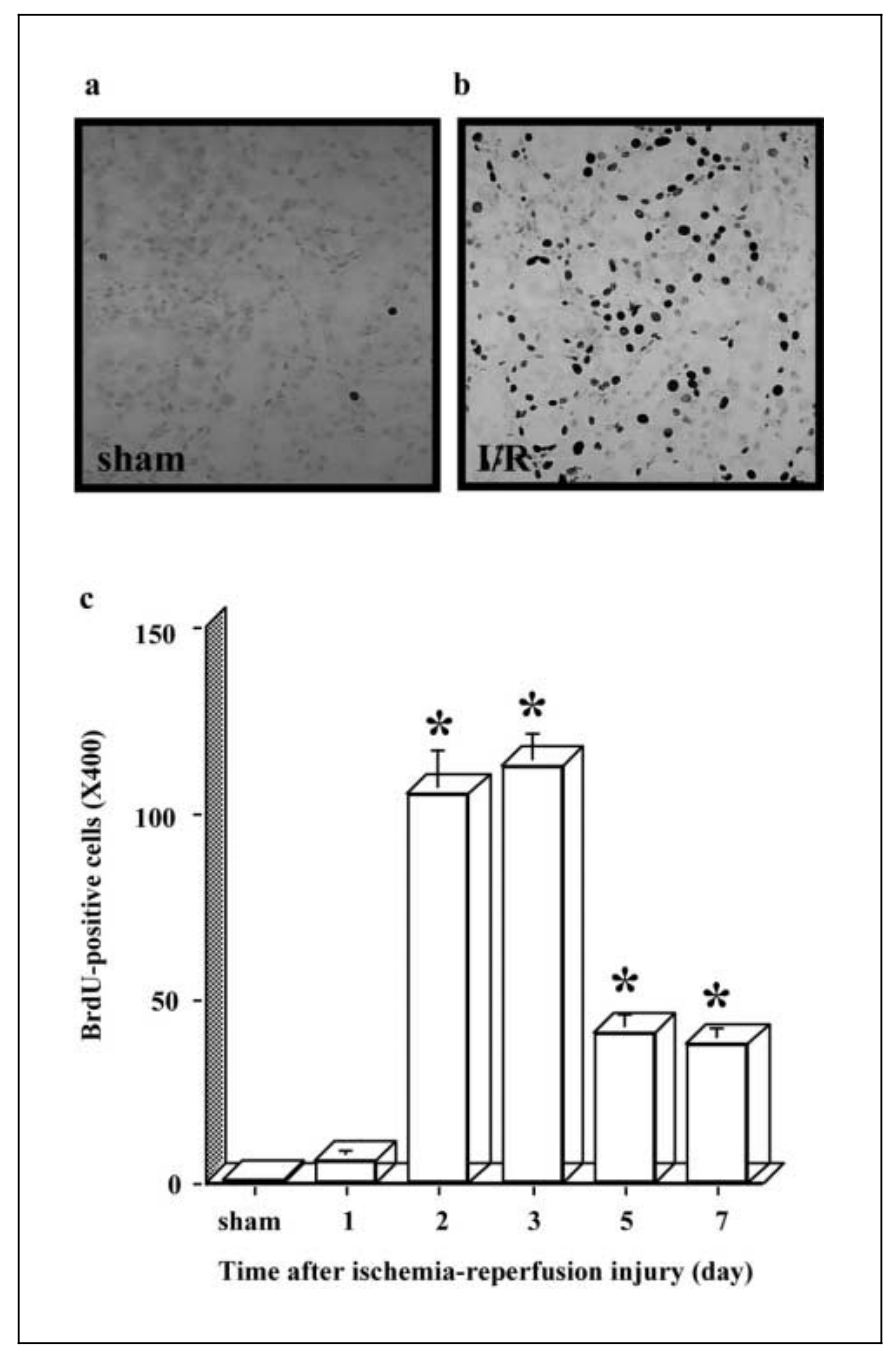

Fig. 2. Immunohistochemical detection of BrdU-positive cells in rat kidney after sham operation or I/R injury. In the sham-operated rat kidney (a), there were few BrdU-positive cells. After ischemic injury (b), numerous BrdU-positive cells were observed in the renal tubular cells on day 2. The number of BrdU-positive cells peaked at days 2-3 after ischemic injury and gradually decreased thereafter $(\mathbf{c}) . \times 100$. $* \mathrm{p}<0.05$ vs. sham-operated rat kidney.

increased slightly on day 1 ( $6 \pm 3$ per field), and increased maximally on day 2 (105 \pm 12 per field) and day $3(113 \pm$ 9 per field), gradually decreasing thereafter (day $5,41 \pm 5$ per field; day 7, $38 \pm 4$ per field).

\section{Influence of CSA or FK506 on Renal Function in Rat Kidney with I/R Injury}

In rat kidneys with $\mathrm{I} / \mathrm{R}$ injury, blood urea nitrogen (BUN: $89 \pm 10$ vs. $29 \pm 6 \mathrm{mg} / \mathrm{dl}, \mathrm{p}<0.01$ ) and serum creatinine levels $(1.63 \pm 0.26$ vs. $0.73 \pm 0.11 \mathrm{mg} / \mathrm{dl}, \mathrm{p}<$ a
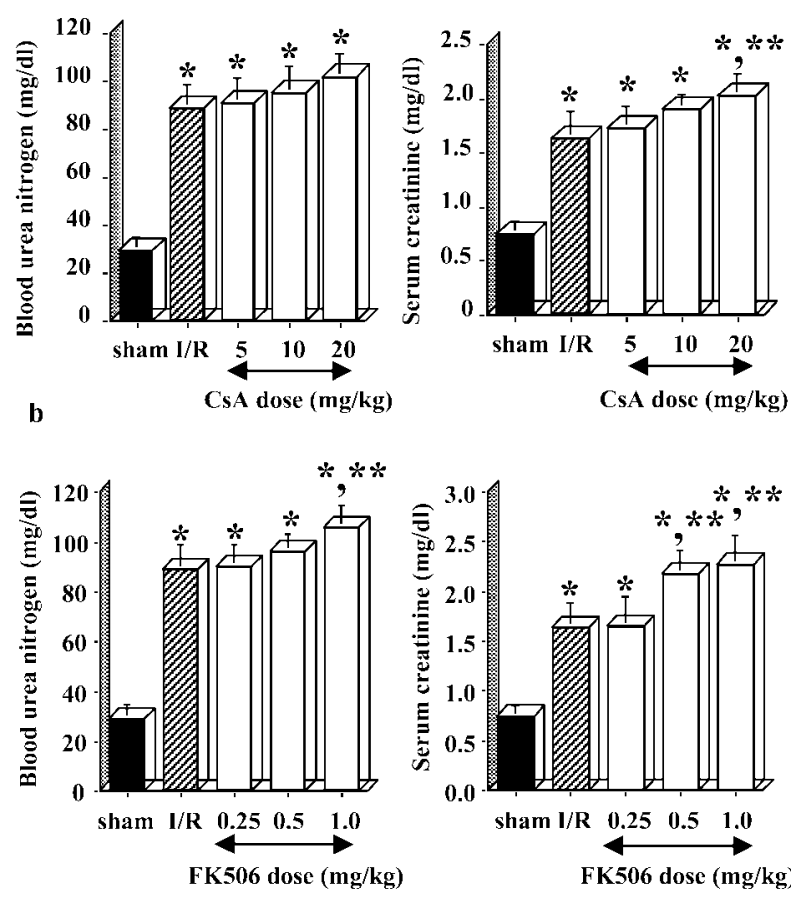

Fig. 3. Influence of CsA (a) and FK506 (b) on renal function in rats with I/R injury. Note the significant increase in BUN and serum creatinine levels in CsA and FK506-treated ischemic rats. ${ }^{*} \mathrm{p}<0.05$ vs. sham-operated rat; ${ }^{* *} \mathrm{p}<0.05$ vs. rats with $\mathrm{I} / \mathrm{R}$ injury.

0.01) were significantly increased compared with the sham-operated controls. The administration of CsA to the ischemic rat further increased BUN and serum creatinine levels, and a statistically significant serum creatinine level was observed with high-dose CsA $(20 \mathrm{mg} / \mathrm{kg})$ when compared with untreated rats with I/R injury $(2.03 \pm 0.21 \mathrm{vs}$. $1.63 \pm 0.26 \mathrm{mg} / \mathrm{dl}, \mathrm{p}<0.05)$. Similar results were observed in FK506-treated rats with I/R injury (fig. 3).

\section{Influence of CsA or FK506 on Acute Tubular Injury in} Rat Kidney with I/R Injury

Figure 4 shows the histological assessment of rat kidneys with I/R injury treated with CsA or FK506. In rat kidney with $I / R$ injury, severely damaged renal tubules were visible at the outer medulla compared with the sham-operated rat kidney. With CsA or FK506 treatment, renal tubular injury scores increased progressively compared with the untreated I/R injury, but significant increases were only observed with high-dose CsA (20 mg/ 


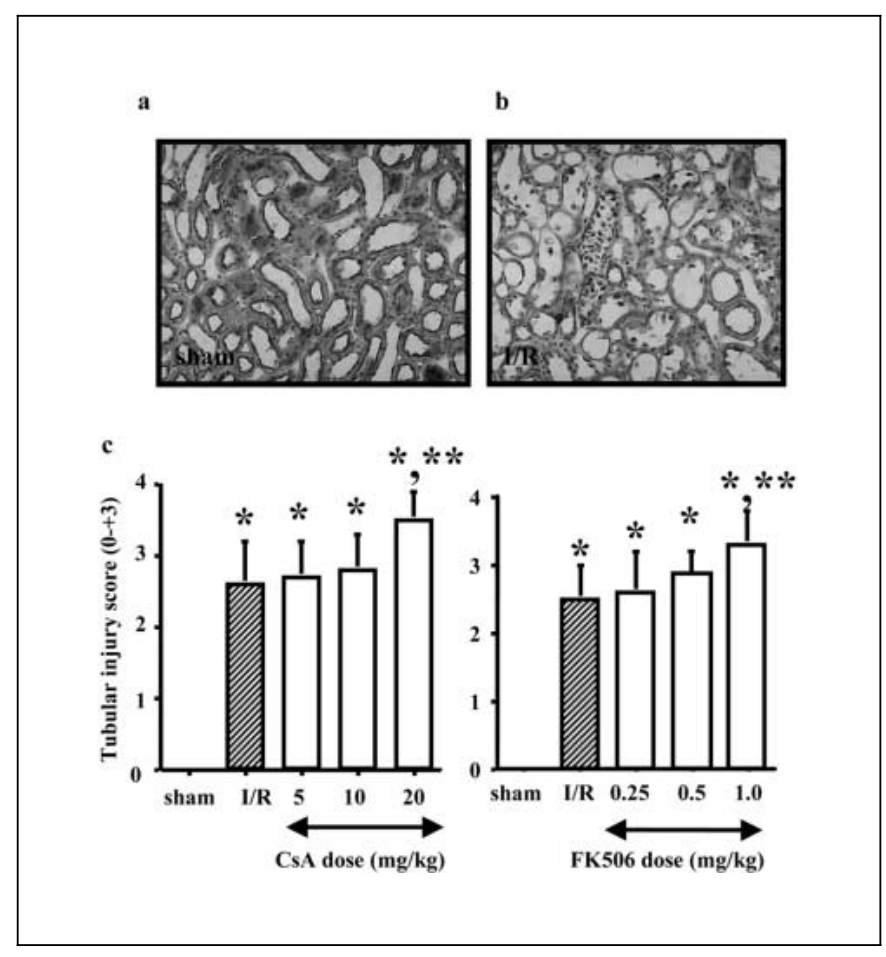

Fig. 4. Influence of CsA (a) and FK506 (b) on acute tubular necrosis in rat kidneys with $\mathrm{I} / \mathrm{R}$ injury. Note that high-dose CsA $(20 \mathrm{mg} / \mathrm{kg})$ or FK506 $(1 \mathrm{mg} / \mathrm{kg})$ increased the tubular injury score compared with the I/R injury group (c). $\times 100 . * \mathrm{p}<0.05$ vs. sham-operated rat kidney; ${ }^{* *} \mathrm{p}<0.05$ vs. rats with $\mathrm{I} / \mathrm{R}$ injury.

$\mathrm{kg}, 2.6 \pm 0.6$ vs. $3.5 \pm 0.4$, respectively; $\mathrm{p}<0.05$ ) or FK506 $(1 \mathrm{mg} / \mathrm{kg}, 2.5 \pm 0.5$ vs. $3.3 \pm 0.5$, respectively; $\mathrm{p}<0.05)$.

\section{CsA or FK506 Levels in Blood at Different Doses}

Figure 5 shows the levels of CsA (a) and FK506 (b) in whole blood. Levels of CsA in whole blood after administration for different doses were: $5 \mathrm{mg} / \mathrm{kg}, 298 \pm 25 \mathrm{ng} / \mathrm{ml}$; $10 \mathrm{mg} / \mathrm{kg}, 580 \pm 45 \mathrm{ng} / \mathrm{ml} ; 20 \mathrm{mg} / \mathrm{kg}, 950 \pm 90 \mathrm{ng} / \mathrm{ml}$. Levels for FK506 in whole blood after administration of different doses were: $0.25 \mathrm{mg} / \mathrm{kg}, 2.0 \pm 0.3 \mathrm{ng} / \mathrm{ml} ; 0.5 \mathrm{mg} /$ $\mathrm{kg}, 2.3 \pm 0.2 \mathrm{ng} / \mathrm{ml} ; 1.0 \mathrm{mg} / \mathrm{kg}, 3.9 \pm 0.4 \mathrm{ng} / \mathrm{ml}$.

\section{Influence of CsA or FK506 on EGF Expression in Rat Kidney with I/R Injury}

Figure 6 shows the influence of CsA on EGF expression in a rat kidney with $\mathrm{I} / \mathrm{R}$ injury. In the cortex, lowdose CsA $(5 \mathrm{mg} / \mathrm{kg})$ significantly reduced EGF expression compared with the untreated rat kidney with $\mathrm{I} / \mathrm{R}$ injury (3.5-fold vs. 29-fold; p < 0.05). In the medulla, the influence of CsA on EGF expression was less marked than

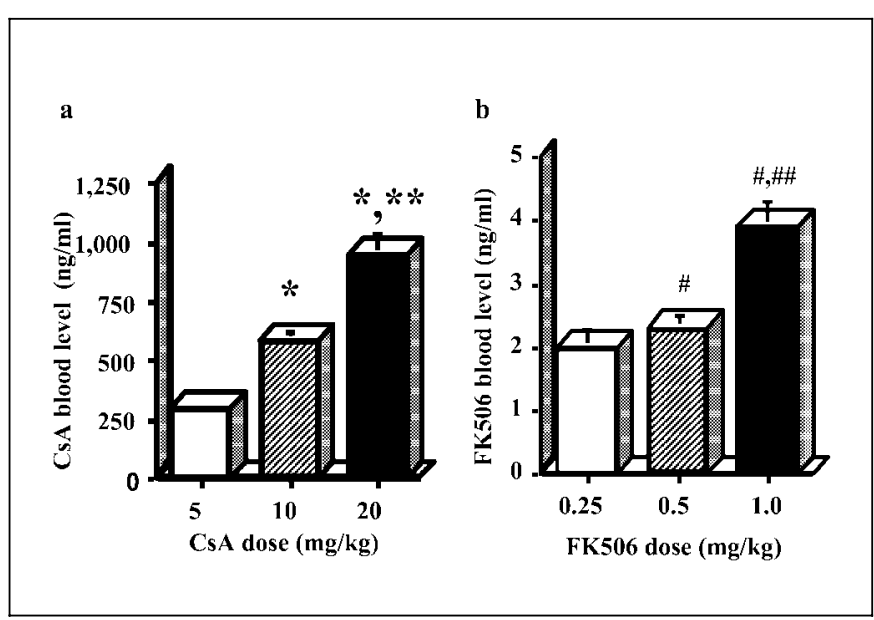

Fig. 5. Blood levels of CsA (a) and FK506 (b) in rats with I/R injury. $* \mathrm{p}<0.05$ vs. CsA $(5 \mathrm{mg} / \mathrm{kg})$ group; ** $\mathrm{p}<0.05$ vs. CsA $(10 \mathrm{mg} / \mathrm{kg})$ group; ${ }^{\#}$ p $<0.05$ vs. FK $506(0.25 \mathrm{mg} / \mathrm{kg})$ group; ${ }^{\# \#}$ p $<0.05$ vs. FK 506 $(0.5 \mathrm{mg} / \mathrm{kg})$ group.

in the cortex, but EGF expression was inhibited dosedependently. FK506-treated rats showed similar patterns (fig. 7). In the cortex, there was significant decrease of EGF expression at a dose of $0.25 \mathrm{mg} / \mathrm{kg}$. In the medulla, the influence of FK506 on EGF expression was less marked than in the cortex, but EGF expression was inhibited dose-dependently $(0.25 \mathrm{mg} / \mathrm{kg}, 10.5$-fold; $0.5 \mathrm{mg} / \mathrm{kg}$, 8 -fold; $1 \mathrm{mg} / \mathrm{kg}, 6.5$-fold; $\mathrm{p}<0.05$ ).

\section{Influence of CSA or FK506 on Renal Tubular \\ Regeneration in Ischemic Rat Kidneys}

Figure 8 shows the dose-dependent inhibition of renal tubular regeneration in CsA- or FK506-treated ischemic rat kidneys. In the CsA-treated kidney, low-dose CsA $(5 \mathrm{mg} / \mathrm{kg})$ significantly reduced the number of BrdU-positive cells compared with the rats with untreated I/R injury ( $80 \pm 7$ vs. $105 \pm 12$ per field, respectively; $p<0.05$ ), and this influence was much greater with high doses of CsA $(10 \mathrm{mg} / \mathrm{kg}, 65 \pm 8$ per field; $20 \mathrm{mg} / \mathrm{kg}, 41 \pm 8$ per field; $\mathrm{p}<0.05$ ). Similar results were observed in the FK506treated ischemic rat kidney. With low-dose FK506 $(0.25 \mathrm{mg} / \mathrm{kg})$ treatment, the number of BrdU-positive cells was significantly decreased compared with the untreated rats with $\mathrm{I} / \mathrm{R}$ injury $(86 \pm 10$ vs. $105 \pm 12$ per field; $p<0.05$ ), and further decreases in the numbers of BrdU-positive cells were observed with high-dose FK506 $(0.5 \mathrm{mg} / \mathrm{kg}, 53 \pm 8$ per field; $1.0 \mathrm{mg} / \mathrm{kg}, 39 \pm 6$ per field; $\mathrm{p}<0.05)$ 


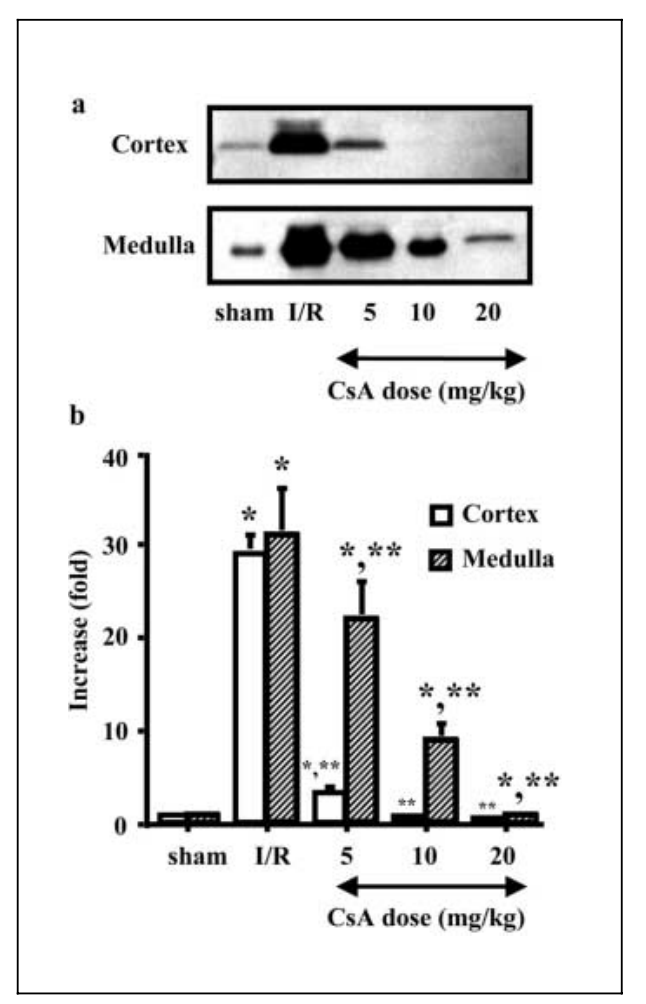

Fig. 6. Immunoblot of EGF expression in CsA-treated ischemic rat kidney. Representative immunoblot for EGF (a) and relative optical densities (b). Note the dose-dependent inhibition of EGF expression in CsA-treated ischemic rat kidney. Optical densities represent the mean \pm SEM from six animals. ${ }^{*} \mathrm{p}<0.05$ vs. sham-operated rat kidney; ${ }^{* *} \mathrm{p}<0.05$ vs. rat kidney with $\mathrm{I} / \mathrm{R}$ injury.

\section{Discussion}

Our study demonstrates the influence of CsA or FK506 treatment on ischemic rat kidney. Treatment of CsA or FK506 in an ischemic rat further aggravated renal function and renal tubular injury. At molecular basis, there was a decrease in EGF expression and renal tubular regeneration in CsA or FK506-treated ischemic rat kidneys compared with rat kidneys with $\mathrm{I} / \mathrm{R}$ injury alone. This finding confirms the nephrotoxic potential of CsA or FK506 in ischemic kidneys, and suggests that CsA or FK506-induced nephrotoxicity is associated with delayed recovery of acute tubular necrosis in ischemic rat kidneys.

Our study focused on mature EGF $(6.3 \mathrm{kD})$, which is biologically active and has a renotrophic action in ischemic rat kidneys [21], and its expression is decreased in rat kidneys with CsA treatment [22]. The molecular mechanism of EGF as a growth factor was studied exten-
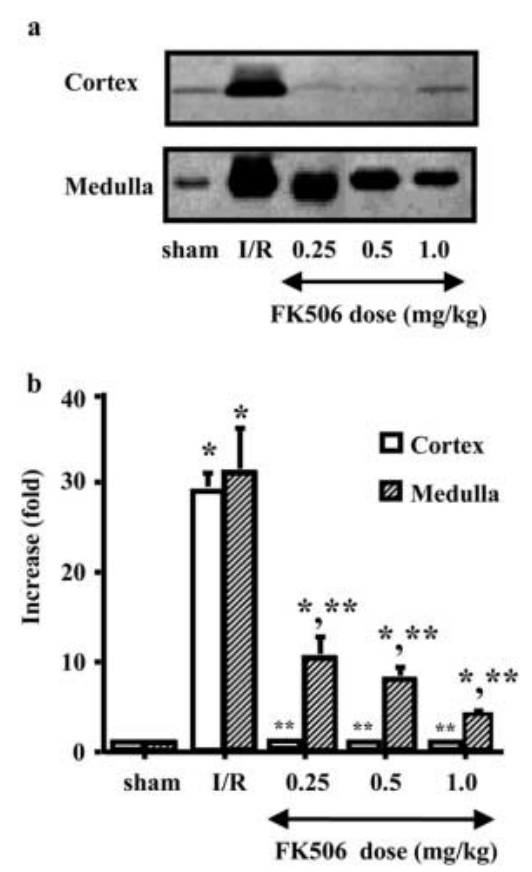

Fig. 7. Immunoblot of EGF expression in FK506-treated ischemic rat kidney. Representative immunoblot for EGF (a) and relative optical densities (b). Note the dose-dependent inhibition of EGF expression in FK506-treated ischemic rat kidney. Optical densities represent the mean \pm SEM from 6 animals. $*$ p $<0.05$ vs. shamoperated rat kidney; ${ }^{* *} \mathrm{p}<0.05$ vs. rat kidney with $\mathrm{I} / \mathrm{R}$ injury.

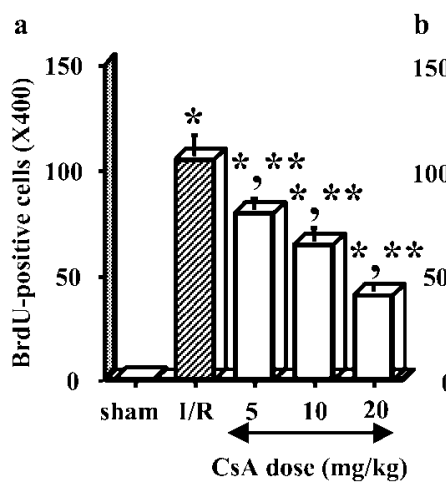

b

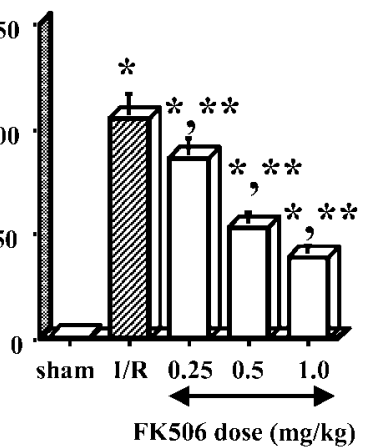

Fig. 8. Influence of CsA (a) or FK506 (b) on renal tubular regeneration in rat kidneys with I/R injury. Note the dose-dependent decrease in the number of BrdU-positive cells in the CsA- and FK506-treated ischemic rat kidneys. ${ }^{*} \mathrm{p}<0.05$ vs. sham-operated rat kidney; ${ }^{* *} \mathrm{p}<$ 0.05 vs. rat kidney with I/R injury. 
sively in an experimental model of $\mathrm{I} / \mathrm{R}$ injury, and data exist in favor of an involvement of EGF in regenerative hyperplasia after renal injury. Exogenously added EGF has been demonstrated to enhance renal tubule cell regeneration as well as to lessen the severity and duration of acute renal failure after hypoxic injury $[15,23]$ or exposure to various nephrotoxins such as mercuric chloride [24], folic acid [25], or gentamicin [26]. In this study, CsA or FK506 treatment to the rats with I/R injury decreased the mature EGF expression. Even in low-dose CsA $(5 \mathrm{mg} /$ $\mathrm{kg})$ and FK506 (0.25 mg/kg), EGF expression was significantly decreased, and further decrease was observed with increasing CsA or FK506 dose. This finding suggests that CsA or FK506-induced nephrotoxicity is closely associated with decreased EGF expression in rat kidneys with $\mathrm{I} / \mathrm{R}$ injury.

There are conflicting results of mature EGF protein after acute tubular necrosis. In rat kidneys with $\mathrm{I} / \mathrm{R}$ injury, EGF immunoreactivity detected by immunohistochemical study decreases [27-29] but concentration of mature EGF rose 7- to 10-fold [21]. At the mRNA level, the EGF precursor [30] and prepro EGF mRNA [31] are decreased during renal tubular regeneration. Thus, it is suggested that that mature EGF protein is present in renal tubular cells as preformed form, and released when kidney is damaged by I/R injury. And then, released mature EGF protein binds to the EGF receptor, which is activated in rat kidneys with $\mathrm{I} / \mathrm{R}$ injury [32]. This assumption may be supported by a previous radiolabeled EGF-binding study, which showed increase of EGF binding to EGF receptor in ischemic kidneys [31]. Based on the above findings, we suggest that increase in mature EGF protein demonstrated by immunoblotting in ischemic rat kidney represents increased binding of mature EGF protein to EGF receptor rather than increased production of mature EGF, and decrease in mature EGF protein in the CsA or FK506-treated rat kidney is related to the decreased EGF binding to EGF receptor.

The results of our study revealed that the peak in EGF expression is at $24 \mathrm{~h}$, and the peak in the number of BrdUpositive cells is at $48-72 \mathrm{~h}$ after ischemic injury. The pattern of EGF expression prior to renal tubular regeneration [21] suggests that EGF may be one of the mitogenic signals triggering regenerative hyperplasia after renal injury and there is a close association between mature EGF protein expression and renal tubular regeneration. However, it is not evident that decrease in mature EGF protein in the CsA or FK506-treated ischemic rat kidneys is causally related to the decreased renal tubular regeneration. On this point, other possibilities should be considered. First,
CsA or FK506 may decrease other growth factors, which are involved in renal regeneration in kidneys with $I / R$ injury [33]. Second, CsA or FK506 may directly inhibit renal tubular regeneration [34]. Therefore, we cautiously propose that the inhibition of EGF by CsA or FK506 may be one of the possible mechanisms of decreased renal tubular regeneration in rat kidneys with $\mathrm{I} / \mathrm{R}$ injury.

In general, CsA treatment in a normal rat does not cause renal dysfunction or morphologic change. However, CsA treatment in ischemic kidney potentiates nephrotoxicity $[19,35]$. This nephrotoxic effect of CsA in the ischemic kidney is time dependent $(30 \rightarrow 60 \mathrm{~min})$ and dosedependent $(5 \rightarrow 10 \rightarrow 25 \mathrm{mg} / \mathrm{kg} /$ day $)$. Our experiment demonstrates that a single subcutaneous injection of CsA (5, $10,20 \mathrm{mg} / \mathrm{kg} /$ day) in rats with ischemic injury deteriorated both renal function and renal structure in a dosedependent manner although significant deterioration was not observed. A similar result was observed in FK506treated rat kidneys. These findings suggest that FK506 as well as CsA has nephrotoxicity in the ischemic rat kidneys.

In summary, our study demonstrates that CsA and FK506 decreases EGF expression in rat kidneys with I/R injury, and that this is closely associated with a decrease in renal tubular regeneration. This suggests that CsA or FK506 may delay the recovery of renal tubular cells from acute tubular necrosis, and this may be related to the decreased intrarenal EGF expression by CsA or FK506.

\section{Acknowledgements}

This work was supported by Korea Research Foundation Grant (KRF-2000-041-F00175). Part of this study was presented in the American Society of Nephrology, San Francisco, Calif., USA, in October 2001 and at the annual meeting of the Korean Society of Internal Medicine, in October 2001. 


\section{References}

1 van Es A, Hermans J, van Bockel JH, Persijn GG, van Hooff JP, de Graeff J: Effect of warm ischemia time and HLA (A and B) matching on renal cadaveric graft survival and rejection episodes. Transplantation 1983;36:255-258.

2 Sanfillippo F, Vaughn WK, Spees EK, Lucas BA: The detrimental effects of delayed graft function in cadaver donor renal transplantation. Transplantation 1984;38:643-648.

3 Cole E, Naimark D, Aprile M, Wade J, Cattran D, Pei Y, Fenton S, Bobinette M, Zaltsman J, Bear R, et al: An analysis of predictors of longterm cadaveric renal allograft survival. Clin Transplant 1995;9:282-288.

4 Troppmann C, Gillingham KJ, Benedetti E, Almond PS, Gruessner RW, Najarian JS, Matas AJ: Delayed graft function, acute rejection, and outcome after cadaver renal transplantation: A multivariate analysis. Transplantation 1995;59:962-968.

5 Goes N, Urmson J, Ramassar V, Halloran PF: Ischemic acute tubular necrosis induces an extensive local cytokine response: Evidence for induction of interferon-r, transforming growth factor, interleukin-2, and interleukin-10, Transplantation 1995;59:565-572.

6 Barros EJ, Boim MA, Ajaen H, Ramos OL, Shor N: Glomerular hemodynamics and hormonal participation on cyclosporine nephrotoxicity. Kidney Int 1987;32:19-25.

7 Toback FG: Regeneration after acute tubular necrosis. Kidney Int 1992;41:226-246.

8 Bacallao R, Fine LG: Molecular events in the organization of renal tubularepithelium: From nephrogenesis to regeneration. Am J Physiol 1989;257:F913-F924

9 Bonventre JV: Mechanisms of ischemic renal failure. Kidney Int 1993;43:1160-1178.

10 Humes HD, Lake EW, Liu S: Renal tubule cell repair following acute renal injury. Miner Electrolyte Metab 1995;21:353-365.

11 Burgess AW: Epidermal growth factor and transforming growth factor $\alpha$. Br Med Bull 1989;45:401-424.

12 Das M, Rengaraju M, Samanta A: Epidermal growth factor; in Aggarwal BB, Gutterman JU (eds): Human Cytokines - Handbook for Basic and Clinical Research. Boston, Blackwell Scientific Publications, 1992, chap 21, pp 365 382.
13 Harris RC: Potential physiologic roles for epidermal growth factor in the kidney. Am J Kidney Dis 1991; 17:627-630.

14 Taub M, Wang Y, Szczesny TM, Kleiman HK: Epidermal growth factor or transforming growth factor $\alpha$ is required for kidney tubulogenesis in matrigel cultures in serum-free medium. Proc Natl Acad Sci USA 1990;87:40024006.

15 Humes HD, Cieslinski DA, Coimbra TM, Messana JM, Galvao C: Epidermal growth factor enhances renal tubular cell regeneration and repair and accelerates the recovery of renal function in postischemic acute renal failure. $\mathrm{J}$ Clin Invest 1989;84:1757-1761.

16 Kanda S, Igawa T, Sakai H, Nomata K, Kanetake H, Saito Y: Anti-epidermal growth factor antibody inhibits compensatory renal hyperplasia but not hypertrophy after unilateral nephrectomy in mice. Biochem Biophys Res Commun 1992;187:1015-1021.

17 Myers BD: Cyclosporine nephrotoxicity. Kidney Int 1986:30:964-974.

18 Barros EJ, Boim MA, Ajzen H, Ramos OL, Schor N: Glomerular hemodynamics and hormonal participation on cyclosporine nephrotoxicity. Kidney Int 1987;32:19-25.

19 Ysebaert DK, De Greef KE, Nouwen EJ, Verpooten GA, Eyskens EJ, De Broe ME: Influence of cyclosporin A on the damage and regeneration of the kidney after severe ischemia/reperfusion injury. Transplant Proc 1997;29:2348-2351.

20 Nonclearcq D, Wrona S, Toubeau G, Zanen J, Heuson-Stiennon JA, Schaudies RP, Laurent $\mathrm{G}$ : Tubular injury and regeneration in the rat kidney following acute exposure to gentamicin: A time-course study. Renal Failure 1992;14: 507-521.

21 Schadies RP, Nonclearcq D, Nelson L, et al: Endogenous EGF as a potential renotrophic factor in ischemia-induced acute renal failure. Am J Physiol 1993;265:F425-F434.

22 Yang CW, Ahn HJ, Kim WY, Shin MJ, Kim SK, Park JH, Kim YO, Kim YS, Kim J, Bang $\mathrm{BK}$ : Influence of renin-angiotensin system on epidermal growth factor expression in normal and cyclosporine-treated rat kidney. Kidney Int 2001;60:847-857.

23 Norman J, Tsau YK, Bacay A, Fine LG: Epidermal growth factor accelerates functional recovery from ischemic acute tubular necrosis in the rat: Role of epidermal growth factor receptor. Clin Sci Lond 1990;78:445-450.
24 Coimbra TM, Cieslinski DA, Humes HD: Epidermal growth factor accelerates renal repair in mercuric chloride nephrotoxins. Am J Physiol 1990;259:F438-F443.

25 Alberti P, Bardella L, Comelli R: Ribosomal protein S6 kinase is activated after folic acid injury and epidermal growth factor administration but not after unilateral nephrectomy in the rat kidney. Nephron 1992;60:330-335.

26 Morin NJ, Laurent G, Nonclereq D, Toubeau $\mathrm{G}$, Heuson-Stiennon JA, Bergeron MG, Beauchamp D: Epidermal growth factor (EGF) accelerates renal tissue repair in a rat model of gentamicin nephrotoxicity. Am J Physiol 1989; 51:123-140.

27 Verstrepen WA, Nouwen EJ, De Broe ME: Altered growth factor expression during toxic proximal tubular necrosis and regeneration. Kidney Int 1993;43:1267-1279.

28 Safirstein R, Zelent AZ, Price PM: Reduced renal prepro-epidermal growth factor mRNA and decreased EGF excretion in ARF. Kidney Int 1989;36:810-815.

29 Toubeau G, Nonclercq D, Zanen J, Laurent G, Schaudies PR, Heuson-Stiennon JA: Renal tissue expression of EGF and EGF receptor after ischaemic tubular injury: An immunohistochemical study. Exp Nephrol 1994;2:229-239.

30 Schadies RP, Johnson JP: Increased soluble EGF after ischemia is accompanied by a decrease in membrane-associated precursors. Am J Physiol 1993;264:F523-F531.

31 Safirstein R, Price PM, Saggi SJ, Harris RC: Changes in gene expression after temporary renal ischemia. Kidney Int 1990;37:15151521.

32 Yano T, Yazima S, Hagiwara K, Ozasa H, Ishizuka S, Horikawa S: Activation of epidermal growth factor receptor in the early phase after renal ischemia-reperfusion in rat. Nephron 1999;81:230-233.

33 Hammerman MR: Growth factors and apoptosis in acute renal injury. Curr Opin Nephrol Hypertens 1998;7:419-424.

34 Bia MJ, Tyler KA: Effect of cyclosporine on renal ischemic injury. Transplantation 1987; 43:800-804.

35 Yang CW, Kim BS, Kim J, Ahn HJ, Park JH, Jin DC, Kim YS, Bang BK: Preconditioning with sodium arsenite inhibits apoptotic cell death in rat kidney with ischemia/reperfusion or cyclosporine-induced injuries. Exp Nephrol 2001;9:284-294. 